\title{
Investigating Foreign Language Speaking Anxiety within the EFL Learner's Interlanguage System: The Case of Iranian Learners
}

\author{
Masoud Mahmoodzadeh \\ Sheikhbahaee University, Isfahan, Iran \\ Email: masoudmahmoodzadeh@yahoo.com
}

\begin{abstract}
The present study is an attempt to investigate the status of the EFL learner's interlanguage system as dealt with foreign language (FL) speaking anxiety in the classroom. The objective of the study is first to specifically determine the extent to which Iranian EFL learners attribute their FL speaking anxiety to the constituents of their interlanguage system and second to indicate the related gender and level-based differences among the participants. To this end, the researcher divided the general notion of interlanguage system into its three main researchable constituents: interlanguage phonology, interlanguage grammar, and 'interlanguage meaning system' and then attempted to design a self-reporting questionnaire with a five Likert-type scale mainly on the basis of FLCAS developed by Horwitz, et. al. (1986). After analyzing the results, the findings indicated that the participants were more likely to attribute their most FL speaking anxiety experienced in the classroom to their interlanguage meaning system as compare with the other two subsets of their interlanguage system. In terms of the gender differences, the results suggested that the female participants were found to be more prone to experiencing FL speaking anxiety within the framework of their interlanguage system. With respect to level differences, the results demonstrated that gaining more FL knowledge may not necessarily lead to a substantial reduction in experiencing FL speaking anxiety, since more proficient participants were more subject to the anxiety-provoking factors within their interlanguage system than less proficient participants.
\end{abstract}

Index Terms - FL speaking anxiety, Interlanguage system, EFL learners

\section{INTRODUCTION}

The ever-growing need for good communication skills in English language has created a huge worldwide demand for achieving a good command of English among its non-native speakers (NNSs) around the globe. And one of the indispensable and crucial aspects of learning English for NNSs in this respect has been to develop a good speaking ability. In fact, since leaning to speak a second or foreign language can usher in an era of change and innovation in any individual's life, NNSs probably tend to perceive their speaking ability as an important criterion for their success. Thus, they may attempt to pursue it more seriously rather than other aspects of foreign language learning. However, learning a second or foreign language is prone to be susceptible to some affective variables. One of these affective variables is Foreign Language Anxiety which, as Worde (1998) discusses, more than half of foreign language learners experience some kinds of it in their language classrooms.

To date, foreign language (FL) anxiety among NNSs has been investigated to a relatively great extent. Research of this kind includes some studies which have aimed at exploring FL anxiety from learners' perspective such as Casado and Dereshiswsky (2004), Granschow et al.(1994), Marwan (2007), Seller (2000), Young (1990) to name but a few. In the realm of FL anxiety studies, they have mainly intended to probe and estimate the FL anxiety factors in relation to the macro-skills included in the broad notion of learner language proficiency. Moreover, FL anxiety has also been viewed from other perspectives, for example, from teachers' perspective (e.g. Aydin, 1999; Jackson, 2001; Kota, 2005; Young, 1992). Nevertheless, to the best of the author's knowledge, even though the learner's interlanguage system is constantly in a state of flux, no research study has been conducted to explore particularly the state of foreign language anxiety from within the learner's interlanguage system. In effect, seemingly, the language anxiety studies conducted so far seem to have mainly delved into the phenomenon of FL anxiety with regard to evaluation of its effects on the learner language proficiency. That is, they have viewed and investigated this issue from the outer circle of the EFL learner's interlanguage system while neglecting the other underlying potential instigators that might bring about anxiety from within this transitional system.

In other words, seemingly the skills constituting the external construct of learner language proficiency are derived from their gradually developed underlying interim segments embedded in the learner's interlanguage system; therefore, both the inner and outer circle of the EFL learner's interlanguage system require to be investigated in a parallel manner, since these two circles seem to be interrelated and thus they both might account for the emergence of FL anxiety in EFL learners. In this case, perhaps there is a need to carry out some studies aimed at investigating the constituents of this 
interim system from within to enable researchers to view FL anxiety from a vantage point. In this sense, any finding manifesting the extent (if any) to which this system is hindered by the negative beliefs learners come to hold about their learning in the class may assist language teachers in identifying the anxiety-provoking factors within the learners' interlanguage system in order to facilitate the development of their interlanguage systems. In light of such a rationale, this study focuses on FL speaking anxiety as one of the affective variables influencing the learner's interlanguage system in an endeavor to take a preliminary step towards approaching FL anxiety from within the framework of this system. In this way, it might put forward some pedagogical implications for EFL teachers which may initiate some changes in their professional teaching methodologies and practices and consequently, provide their learners with more efficient feedback due to their awareness of the status of their learners' interlanguage system while dealing with FL speaking anxiety in the classroom.

\section{THEORETICAL BACKGROUND}

\section{A. Defining the Concept of Interlanguage}

Interlanguage theory, proposed by Selinker (1972), concerns with the question of systematicity and variability in the performance of language learners, the question of how the emerging system develops and the role of transfer from the first language in this process. As argued by Selinker,

The interlanguage, a separate linguistic system resulting from the learner's attempted production of the target language norm, is the product of five central cognitive processes involved in second language learning: (1) language transfer: some items (2) Transfer of training. (3) Strategies of second language learning. (4) Strategies of second language communication. (5) Overgeneralization of the target language linguistic materials (cited in McLaughlin, 1987, p. 61).

As discussed by Brown (2000), interlanguage refers to the "separateness of a second language learner's system, a system that has a structurally intermediate status between the native and target languages. This is neither the system of the native language nor the system of the target language, but a system based up on both languages" (pp. 215-216). Nonetheless, this language, like any other natural language, is systematically variable (Tarone, 1983) and thus can be influenced by both cognitive and affective variables. Furthermore, as Ellis (1997) discusses, the learner's interlanguage system can be studied from its various interconnected aspects, for example, from its social aspects, discourse aspects, and psycholinguistic aspects. However, the focus of the present study is on the investigation of the EFL learner's interlanguage system from a linguistic aspect.

\section{B. Defining Language Anxiety}

In general, Spielberger (1983) defines anxiety as the subjective feeling of tension, apprehension, nervousness and worry associated with the arousal of the nervous system. However, in attempting to define language anxiety, Scovel (1978) argues that it should be born in mind that even though we all know what language anxiety is and we all have experienced feelings of anxiousness, anxiety is still not easy to define in a simple sentence. "It is associated with feelings of uneasiness, frustration, self -doubt, apprehension, or worry" (as cited in Brown, 2000, p. 151). To put it in another word, anxiety can be generally associated with "threats to self-efficacy and appraisals of situations as threatening" (Pappamihiel, 2002, p. 331). In addition, Gregersen (2005) argues that learners who feel anxious in their foreign language learning may find their study less enjoyable. In case of the conducted studies on foreign language anxiety (e.g., Aida, 1994; Macintyre, et. al., 1997), a review of the literature has shown that foreign language anxiety is negatively related to foreign language learning. However, in the light of the studies directed at examining the correlation between anxiety and language learning thus far, the overall findings are fairly inconsistent and contradictory. For example, Young (1991) reviews sixteen studies investigating the relationship between anxiety and language learning and demonstrates inconsistent results both within and across these studies. Accordingly, as Young maintains "research in the area of anxiety as it relates to second or foreign language learning and performance is scattered and inconclusive" (p. 426).

\section{Factors Contributing to FL Anxiety}

The components of foreign language anxiety have been identified (Horwitz, et. al., 1986; MacIntyre \& Gardner, 1989) to narrow down this concept into researchable issues: (1) communication apprehension or anxiety. (2) Fear of negative evaluation. (3) Test anxiety. The consolidation of these factors thus leads to the creation of anxiety in language learners. Communication apprehension generally refers to a type of anxiety experienced in interpersonal communicative settings (McCroskey, 1987) which is obviously relevant to second/foreign language learning contexts. In language classrooms where learners have little control of the communicative situation, and their performance is constantly monitored by both their teacher and peers (Horwitz, et. al., 1986), communication apprehension seems to be augmented in relation to the learners' negative self-perceptions caused by the inability to understand others and make themselves understood (MacIntyre \& Gardner, 1989). In other words, communication apprehension is a type of shyness characterized by fear of and anxiety about communicating with people. Difficulty in speaking in public, in listening or learning a spoken message is the manifestation of communicative apprehension. Communication 
apprehension in foreign language learning derives from the personal knowledge that one will almost have difficulty understanding others and making oneself understood (Cubukcu, 2007).

Regarding the fear of negative evaluation, as Young (1991) argues, "students are more concerned about how (i.e., when, what, where, or how often) their mistakes are corrected rather than whether error correction should be administered in class" (p. 429). In this sense, it seems that teachers' beliefs about language teaching may act as some obstacles for L2 learners and thus create language anxiety in them because the assumptions of teachers as to their role in the language classroom may not always correspond to the individual needs or expectations that L2 learners would consider for their teachers.

Test anxiety refers to a type of performance anxiety stemming from a fear of failure. Test anxious students often put unrealistic demands on themselves. Test anxiety is likewise believed to be one of the most important aspects of negative motivation. It can be defined as "unpleasant feeling or emotional state that has physiological and behavioral concomitants and that is experienced in formal testing or other evaluative situations" (Dusek 1980, p. 88). With regard to test anxiety, many of the learners feel more pressure when asked to perform in a foreign/second language, because they are certainly challenged by the fact that they need to recall and coordinate many grammar points at the same time during the limited test period. As a result, they may put down the wrong answer or simply freeze up due to nervousness, even if they know the correct answer (MacIntyre \& Gardner, 1994; Price, 1991).

Moreover, some scholars have endeavored to investigate the types of learning activities in terms of FL anxiety; for example, Horwitz (2001) argues that language learners feel more comfortable in pair work and personalized activities, but this is a relative concept; some activities judged as comfortable by some are also regarded as stressful by others. It is also worth mentioning that, some researchers have attributed other factors to foreign language anxiety. For example, Cubukcu (2007) identifies the main sources of anxiety in the following: "(a) presenting before the class, (b) making mistakes, (c) losing face, (d) inability to express oneself, (e) fear of failure, (f) teachers, and (g) fear of living up to the standards" (p. 133). According to Cubukcu, teachers should consider the possibility that anxiety accounts for the student behaviors before associating poor student performance with the lack of ability, inadequate background or poor motivation.

\section{Effect of FL Anxiety on Learners}

Over the past decades, the general impacts of FL anxiety on learners have produced conflicting results. Many educators and researchers have suggested that FL anxiety can have negative effects on learners' speaking ability. For example, Onwuegbuzie, et. al. (1999) argue that the existence of foreign language anxiety can affect negatively the fluency of learners' speech and learning in a general sense. Likewise, Na (2007), and Spielmann and Radnofsky (2001) have explored FL anxiety among different EFL learners and have maintained that FL anxiety can generally impact negatively on learners' performance. In this sense, Levine (2003) reports that students who come from monolingual backgrounds also tend to feel more anxious than students who come from bi-or multilingual backgrounds. Also, Goshi (2005) suggests that students with negative beliefs about their learning English feel more foreign language anxiety.

In contrast, some other researchers have assumed a positive role for language anxiety in terms of foreign language learning (see for example, Alpert \& Haber, 1960; Chastain, 1975; Kleinmann, 1977). In this sense, Bailey (1983) suggests the benefit of anxiety in language learning. Bailey studied students' diaries to analyze their competitiveness and anxiety during a language class. The students' comments centered on four major themes: (1) their reaction to the class, (2) their preference for a democratic class, (3) their need to succeed and to receive positive reinforcement, and (4) their competitiveness. In general, their anxiety grew out of their apprehension of having to communicate, their concern about tests, and their fear of negative evaluation. In the end, the study explained the positive effects of competitiveness by means of the formation of facilitative anxiety in learners.

\section{E. Effect of FL Anxiety on Productive Skills (Speaking \& Writing)}

Several investigators (e.g. Aida, 1994; Chang, 1996) have examined the effects of FL anxiety on the oral performance in the classroom. To elaborate more on these studies, two of them are particularly discussed here. Ganschow et al. (1994) did a study exploring differences in foreign language anxiety and native oral and written language skills among college students. The results of the study revealed that students significantly differ in their English oral and written achievements in terms of the amount of FL anxiety they suffer from. In another study, Young (1990) investigated the students' perspective on anxiety and speaking. To this end, a questionnaire was designed to identify sources of anxiety over speaking in FL and then was administered to 135 university level Spanish students and 109 high school students. Results of the data analysis indicated that speaking in FL was not exclusively the source of student anxiety, but that speaking in front of the class was. (cited in Chang-Cheng, 2005). On the other hand, some investigators have studied writing apprehension and its effect on students' performance in FL courses (e.g. Cheng, 2002; Cheng, et. al., 1999; Daly \& Wilson, 1983).For example, Saito and Samimy (1996) examined the relationship between anxiety and the study of Japanese and noted that attitude and motivation, along with anxiety, were crucial factors affecting student performance over time.

\section{F. Effect of FL Anxiety on Receptive Skills (Reading \& Listening)}


Sellers (2000) devoted an outstanding study to examining the relationship between language anxiety and reading comprehension in Spanish as a foreign language. The issues addressed were: (1) the effects language anxiety on the reading comprehension and recall of university level language student (2) the effects of language anxiety on the reading process itself. The results revealed that anxiety does affect the reader's concentration on a reading task and on the comprehension of the passage. On the contrary, Matsuda and Gobel (2001) investigated the possible link between foreign language classroom anxiety (FLCA) and foreign language reading anxiety (FLRA) among Japanese university students and reported the results that contradicted the above-mentioned results, that is, they found that FLCA and FLRA are clearly independent constructs. Likewise, Sadighi, et. al. (2009) examined the relationship between listening comprehension (LC) and FLCA among Iranian university students and found that there was no relation between LC and FLCA.

On the other hand, several researchers have also aimed at studying anxiety and its relationship to listening comprehension (e.g. Bacon, 1989; Elkhafaifi, 2005; Gardner, et. al., 1987; Lund, 1991). The corollary of these studies have manifested that anxiety impedes listening comprehension. For example, Elkhafaifi (2005) examined the relationship between listening FL anxiety and listening comprehension in Arabic language classrooms and came up with the similar results being consonant with the above-mentioned results, that is, listening anxiety like other language skills also correlates negatively with listening achievement.

\section{Methodology}

\section{A. Questions}

The present study seeks to find the answers to the following research questions:

1. To what extent do Iranian EFL learners attribute their FL speaking anxiety to the three constituents of their interlanguage system (i.e. phonology, grammar, \& meaning)?

2. Which of the three constituents of Iranian EFL learners' interlanguage system is more subject to FL speaking anxiety arousals?

3. Are there any significant differences in the degree of FL speaking anxiety between the learners' gender?

4. Are there any significant differences in the degree of FL speaking anxiety between the learners' course levels (i.e. Lower Intermediate \& Upper Intermediate)?

\section{B. Participants}

The participants involved in the present study comprised 74 Iranian EFL learners studying English at two affiliated branches of an English language institute in Mashhad. The subjects were selected through a convenience sampling including 31 males and 43 females. The age of the learners ranged from 14 to 23 with the mean of 17.5 years. One half of the learners were learning English at Lower Intermediate level and the other half of the learners were learning English at Upper Intermediate level. The criterion of the aforementioned English language institute for placement of the EFL learners was based on ACTFL Oral proficiency Interview (OPI) following the ACTFL Proficiency Guide Lines (Novice Low, Novice Mid, Novice High, Intermediate Low, Intermediate Mid, Intermediate High, Advance Low, Advance Mid, Advanced High, and Superior).

In addition, not only the population of the study needed to be identified, but also the intended features of sub-groups within the population (i.e. gender \& course level) needed to be precisely determined in the present study. To do so, the stratified random sample was employed to select the participants; therefore, the early population sample included 106 learners. But in order to consider the homogeneity of the sample of the study, it was decided to calculate the mean of the learners' exam scores obtained during their three pervious semesters and then the learners with the average scores of one standard deviation above or below the mean of total scores were only allowed to incorporate into the final sample. Hence, the size of the sample reduced to 74 subjects and consequently, 32 learners (nearly $30 \%$ ) were excluded from the early population sample. Meanwhile, it is worth mentioning that the two affiliated branches of the English language institutes in question were quite similar in terms of the educational system, course books, and even their teacher staff and the only visible difference was the location of these two branches.

\section{Instrument}

The most well-known instrument for measuring FL classroom anxiety has been Foreign Language Classroom Anxiety Scale (FLCAS) during the last decades due to its high validity and reliability. However, since oral performance is underscored in this study, the researcher attempted to modify some of the items included in FLCAS (Horwitz, et. al., 1986). To this end, first the researcher divided the general notion of interlanguage system into its three main researchable subsets: interlanguage phonology, interlanguage grammar, and 'interlanguage meaning system' . In this way, it was felt possible to investigate the impacts of FL speaking anxiety on the above constituents of the learner's interlanguage system. Furthermore, it should be noted that the defined 'interlanguage meaning system' in the study refers to the learner's semantic, lexical and discoursal knowledge of the target language. Second, the researcher attempted to develop a self-reporting questionnaire mainly on the basis of the FLCAS due to its well-established validity and reliability. So, some items in the inventory of the FLCAS were totally deleted or were modified to meet the needs of the study and to enhance the suitability of the item construction (See Appendix A). 
In addition, to make sure that the participants had no problem in understanding the questionnaire, the developed self-reporting questionnaire was then translated from English version into Persian version (See Appendix B). In order to avoid the translation task from having any biased impact on the results of the questionnaire and also to consider more cautiously the cross-culturally ethnocentric problems in this affectivity test, the procedure of back translation was used to validate the Persian questionnaire. Therefore, three English language teachers translated the original questionnaire into Persian and three others back translated the Persian questionnaire into English. An expert on translation was then asked to validate the translated English version. He approved of the similarity between the two versions. In this way, the validity of the translated version was endorsed.

The designed questionnaire consisted of 18 items measuring FL speaking anxiety within the frame of EFL learners' interlanguage phonology, interlanguage grammar, and 'interlanguage meaning system'. The items are illustrated below:

*Items measuring FL speaking anxiety in terms of the EFL learner's interlanguage phonology: 1, 4, 7, 10, $13,16$.

*Items measuring FL speaking anxiety in terms of the EFL learner's interlanguage grammar: 2, 5, 8, 11, $14,17$.

*Items measuring FL speaking anxiety in terms of the EFL learner's 'interlanguage meaning system': 3, 6, 9, 12, 15, 18.

\section{Procedure}

To assess the internal consistency reliability of the items included in the translated questionnaire, a pilot test was administered among 17 subjects randomly selected from the whole population in question. The results showed the internal consistency reliability, achieving an alpha coefficient of .82 in the pilot run. And, since George and Mallery (2003) suggest that items can be claimed to have a high degree of reliability if they achieve a score of .80 or higher in the reliability statistics; therefore, the items in the designed questionnaire indicated a relatively high degree of internal consistency as the alpha value was greater than .80. After the pilot test, the ambiguities and misunderstanding of items were recognized and some of the items bearing extreme scores were revised to assure a higher reliability. In addition, a few changes were also made in the introductory instruction of the questionnaire to increase the reliability of questionnaire. To collect the necessary data, the questionnaire was distributed among the participants in question while adequate time was given to them to complete it.

\section{RESULTS}

To answer the research questions, the data were collected and analyzed quantitatively using SPSS. Firstly, to estimate the extent to which Iranian EFL learners attribute their FL speaking anxiety to the three constituents of their interlanguage systems under investigation, the average mean scores of participants' responses to the questionnaire items were calculated out of the possible maximum mean score of 30 . Furthermore, it should be noted that when the statements of the designed questionnaire were negatively worded, responses were reversed and then were computed. In this way, a high score in all likelihood represented high anxiety. The achieved results are illustrated below:

TABLE1.

DESCRIPTIVE STATISTICS FOR THE PARTICIPANTS' SCORES

\begin{tabular}{|l|l|l|l|l|l|}
\hline & N0. of items & Min. & Max. & Mean & SD \\
\hline Interlanguage phonology & 6 & 8 & 18 & 13.8 & 3.8 \\
\hline Interlanguage grammar & 6 & 13 & 23 & 20.4 & $2 . .5$ \\
\hline 'Interlanguage meaning system' & 6 & 17 & 27 & 24.7 & 3.4 \\
\hline
\end{tabular}

As shown in Table 1, the participants reported the overall mean score of 13.8 for items measuring FL speaking anxiety related to their interlanguage phonology with a standard deviation of 3.8, the overall mean score of 20.4 for items measuring FL speaking anxiety related to their interlanguage grammar with a lower standard deviation of 2.5, and the overall mean score of 24.7 for items measuring FL speaking anxiety related to their interlanguage meaning system with a standard deviation of 3.4. To display more specifically the obtained results for the questionnaire items, they are illustrated in the following:

TABLE 2.

DESCRIPTIVE STATISTICS FOR THE QUESTIONNAIRE ITEMS BASED ON THE PARTICIPANTS' SCORES

\begin{tabular}{|l|l|l|c|}
\hline & N0. of items & Mean & SD \\
\hline Interlanguage phonology & $1,4,7,10,13,16$ & 2.3 & .63 \\
\hline Interlanguage grammar & $2,5,8,11,14,17$ & 3.4 & .41 \\
\hline 'Interlanguage meaning system' & $3,6,9,12,15,18$ & 4.1 & .57 \\
\hline
\end{tabular}




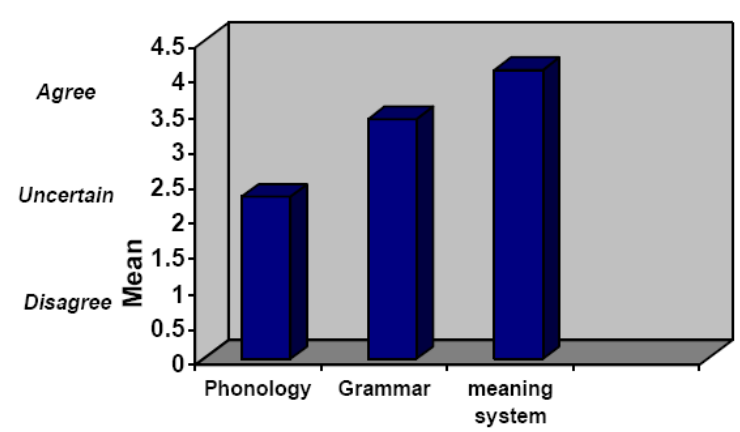

Figure1. Comparison of the anxiety factors within the participants' interlanguage system

As can be seen in Figure 1, it appears that the degrees of FL speaking anxiety that the participants indicated for the categorized constituents of their interlanguage system in the questionnaire items varied significantly. More particularly, on the one hand, in terms of interlanguage phonology, the relevant questionnaire items did not evoke a relatively high degree of FL speaking anxiety, since the participants reported a rather small amount of FL speaking anxiety for their interlanguage phonology $(\mathrm{M}=2.3)$ as compared with the other two related categories in the questionnaire. Therefore, seemingly, the participants are not very anxious about their L2 pronunciation or accent while speaking a foreign language in the classroom. On the other hand, the participants reported statistically substantial amounts of FL speaking anxiety for their interlanguage grammar and meaning system (i.e. $\mathrm{M}=3.4 \& \mathrm{M}=4.1$, respectively) suggesting that the participants may suffer more FL speaking anxiety from these two constituents of their interlanguage system.

In addition, the status of the participants' interlanguage system as dealt with FL speaking anxiety is presented based on different course levels and genders in the following figures respectively:

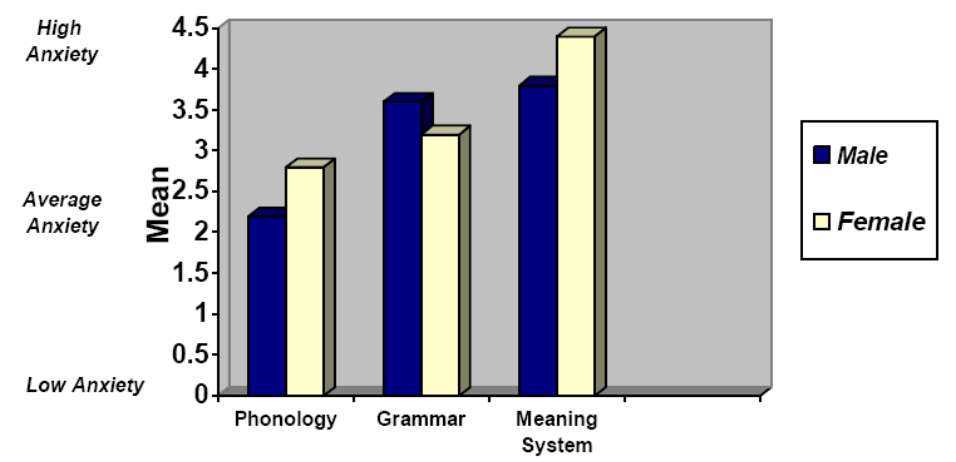

Figure 2. Comparing gender-based differences in the overall means of FL speaking anxiety among the participants

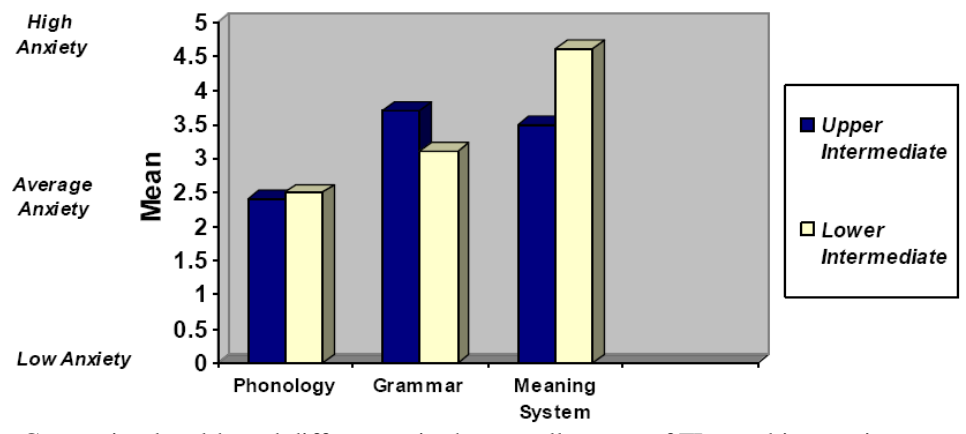

Figure 3. Comparing level-based differences in the overall means of FL speaking anxiety across the two groups

As can be observed in Figure 2, regarding the gender-related differences, the participants did not report mutual amounts of FL speaking anxiety for the categories in question. In fact, the findings suggested that the female participants might experience relatively greater amount of FL speaking anxiety for the items related to interlanguage phonology and meaning system (i.e. $\mathrm{M}=2.8 \& \mathrm{M}=4.4$, respectively) as compared with the male ones. Moreover, it should be mentioned that the male participants experienced relatively more FL speaking anxiety with respect to their interlanguage grammar $(M=3.6)$ in comparison with female ones $(M=3.2)$.

Further, according to Figure 3, it seems that the participants almost experience similar amount of FL speaking anxiety in the classroom in terms of their interlanguage phonology across the two levels, namely Upper Intermediate and Lower Intermediate. In contrast to this similarity, the participants across the levels indicated statistically varying amounts of FL speaking anxiety for their interlanguage grammar and meaning system. In effect, the results showed that the Lower Intermediate learners were found to significantly exceed the Upper intermediate learners with regard to the 
reported amount of FL speaking anxiety for their interlanguage meaning system, whereas the Upper Intermediate learners were found to exceed the Lower Intermediate learners in terms of the reported amount of FL speaking anxiety for their interlanguage grammar system.

\section{DISCUSSION}

To address the first two research questions, the overall findings of the study suggested that the Iranian EFL learners under study are likely to attribute their most FL speaking anxiety in the classroom to their interlanguage meaning system while they may attribute their FL speaking anxiety in the classroom more to their interlanguage grammar rather than to their interlanguage phonology. In fact, among the three constituents of the Iranian EFL learners' interlanguage system, their interlanguage meaning system might be considered as the most potential instigator for their FL speaking anxiety in the classroom. In a nutshell, it is safe to mention that since the Iranian EFL learners under study tend to experience a rather small degree of FL speaking anxiety for their interlanguage phonology in comparison with the other two categories in the study, they are perhaps more concerned about conveying their meanings to their interlocutors than being concerned about their pronunciation while speaking English in the classroom. One possible reason for such phenomenon traces back in part to the phonological similarities existing between Persian and English language. In other words, seemingly, Iranian EFL learners are able to learn to reduce their phonological variations from the target language phonology. One possible explanation is that the phonological forms are learned better due to their transfer from the learners' L1. That is, turning a non-native or non-standard English pronunciation into a native-like or standard one is generally within the Persian speaking EFL learner's capabilities and if some of the learners fail to do so, it is perhaps not due to phonological anxiety factors.

Furthermore, with regard to the third research question, the corollaries of the study also showed that the female participants might suffer from relatively greater amount of FL speaking anxiety with respect to their interlanguage phonology and meaning system as compared with the male ones. Nevertheless, the female participants were found to experience relatively less FL speaking anxiety with respect to their interlanguage grammar than the male ones.

Finally, with respect to the last research question, the results of the study demonstrated that the Upper Intermediate EFL learners seem to perceive more FL speaking anxiety with respect to their interlanguage grammar and meaning system as compared with the Lower Intermediate learners. Therefore, the results corroborated the findings of the pervious language anxiety studies, for example, the study of Sito and Samimy (1996) in which they suggest that the influence of foreign language anxiety becomes more important as the instructional levels of learners increase. In the light of such findings, one possible explanation is that more proficient learners have developed a significantly broader range of English knowledge and as a result, they have become acquainted with so many grammatical structures, vocabulary items, and other language forms. Hence, they are perhaps more susceptible to FL speaking anxiety-provoking factors than less proficient learners on account of having access to more complex FL knowledge. In sum, the findings suggest that gaining more FL knowledge may not necessarily guarantee against FL speaking anxiety in the classroom.

\section{CONCLUSION}

In the present study, it was suggested that investigating the effects of FL anxiety only on the surface of the language skills does not suffice and the underlying elements of these skills need to be scrutinized within the framework of the interlanguage system as well. Thus, the study might have some pedagogical implications for EFL teachers, especially for Iranian teachers. According to the findings, perhaps one of the implications of the study is that Iranian EFL teachers need to indicate and show verbally or non-verbally that they understand what their learners mean while they are attempting to convey their meanings in the classroom. In this way, teachers can develop rapport with their learners and may help them to alleviate their FL speaking anxiety, since the learners' interlanguage meaning system is considerably subject to FL speaking anxiety notwithstanding the course levels. Likewise, concerning the gender-related differences, the findings suggest that Iranian teachers bear in mind that female learners are more likely to experience FL speaking anxiety than male learners; therefore, teachers are suggested to support them more with positive feedbacks and avoid employing direct negative feedbacks while they are speaking in the classroom.

However, like all other studies, the current study is not certainly without any limitations. One of the limitations is that the small sample size restricts the generalization of findings of the study. Thus, there is an essential need for future research to cross-validate findings from the present study to a different and larger sample. Another limitation of the study is that it does not specifically address FL speaking anxiety in terms of the related social and pragmatic aspects of the learner's interlanguage system which may also account for some of the learners' FL speaking anxiety in the classroom. Thus, it is suggested that some future studies be planned to investigate the pragmatic aspects of the learner's interlanguage system as dealt with FL speaking anxiety in the classroom across the various cultures.

APPENDix A ENGLish Version of THE DESIGNED QuestionnAire 
Statements (1) through (18) describe how you feel about speaking English. Please read the statements carefully and give your first reaction by choosing an answer for each statement: (1) strongly Disagree, (2) Disagree, (3) Neither Agree nor Disagree (4) Agree, or (5) Strongly Agree.

\section{Personal information:}

Gender: Male Female

Age:

1) I never feel quite sure of myself when I am pronouncing English words in my language class.

$\begin{array}{lllll}1 & 2 & 3 & 4 & 5\end{array}$

2) I am usually at ease when using grammar in my speaking in my language class.

$\begin{array}{lllll}1 & 2 & 3 & 4 & 5\end{array}$

3) I get tense and confused when the teacher does not understand what I mean in English.

$\begin{array}{lllll}1 & 2 & 3 & 4 & 5\end{array}$

4) I keep thinking that the other students have better English accents than I do.

$\begin{array}{lllll}1 & 2 & 3 & 4 & 5\end{array}$

5) In my language class, it bothers me when I can not speak English very much because of my grammar.

$\begin{array}{lllll}1 & 2 & 3 & 4 & 5\end{array}$

6) I start to panic when I am not sure of saying something that makes sense in English.

$\begin{array}{lllll}1 & 2 & 3 & 4 & 5\end{array}$

7) I never feel embarrassed when other students are hearing my English accent in my language class.

$\begin{array}{lllll}1 & 2 & 3 & 4 & 5\end{array}$

8) I would be worried failing to use correct grammar in my speaking in my language class.

$\begin{array}{lllll}1 & 2 & 3 & 4 & 5\end{array}$

9) I can feel my heart pounding when the teacher asks me the question; "what do you mean?"

$\begin{array}{lllll}1 & 2 & 3 & 4 & 5\end{array}$

10) The more I try to speak English fluently in the class, the more disappointed I get.

$\begin{array}{llllll}1 & 2 & 3 & 4 & 5\end{array}$

11) I wonder why some people feel very self-conscious when teacher corrects their grammatical mistakes.

$\begin{array}{lllll}1 & 2 & 3 & 4 & 5\end{array}$

12) While speaking in my language class, I feel intimidated when I translate word by word the expressions from my native language into English language.

$\begin{array}{lllll}1 & 2 & 3 & 4 & 5\end{array}$

13) It bothers me when I can not speak English with a good accent in my language class

$\begin{array}{lllll}1 & 2 & 3 & 4 & 5\end{array}$

14) When I want to use correct grammar to speak English in the class, I get so nervous that I forget what to say.

$\begin{array}{lllll}1 & 2 & 3 & 4 & 5\end{array}$

15) In my language class, I feel pressured when I use English sentences not heard before.

$\begin{array}{lllll}1 & 2 & 3 & 4 & 5\end{array}$

16) I always feel that the other students will laugh at my accent as I speak English in class.

$\begin{array}{lllll}1 & 2 & 3 & 4 & 5\end{array}$

17) It frightens me when I can not speak English without any grammatical mistakes in the class.

$\begin{array}{lllll}1 & 2 & 3 & 4 & 5\end{array}$

18) I do not feel afraid when the teacher does not understand what I mean in English.

$\begin{array}{lllll}1 & 2 & 3 & 4 & 5\end{array}$

APPEndix B Persian Version of the Designed Questionnaire

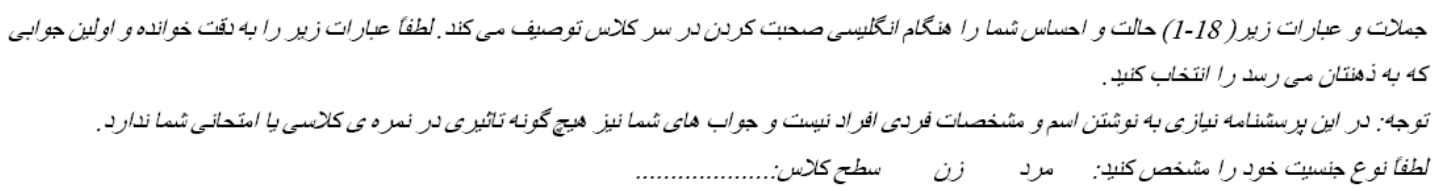




\begin{tabular}{|c|c|c|c|c|c|c|}
\hline مخالفمــاملا كـ & 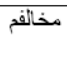 & 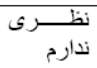 & مو افقم & 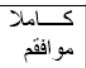 & جملات & $\stackrel{?}{?}$. \\
\hline & & & & & نيسنَمى كه كلمات انكلينى را سر كلاس زبان تلفظ مى كنم هيج وقت خيلى به خودم مطمئن & 1 \\
\hline & & & & & 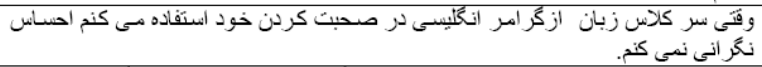 & 2 \\
\hline & & & & & وقتى كه سر كلاس ز بان معلم منظور من را به انكلِيسى نمى فهد احساس نكخر انى مى كنم. & 3 \\
\hline & & & & & 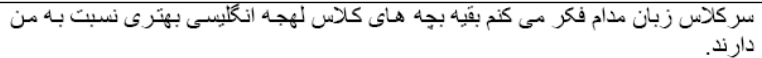 & 4 \\
\hline & & & & & 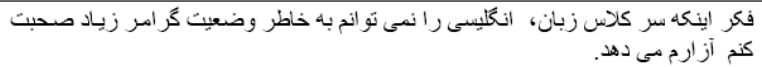 & 5 \\
\hline & & & & & 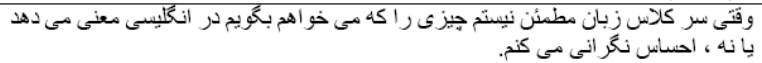 & 6 \\
\hline & & & & & ووقتى سر كلاس زبان بجه ها لهجه انكلينسى من ر ا مى ثُوند اصلا خجالت نمى كثّم. & 7 \\
\hline & & & & & 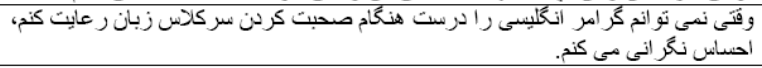 & 8 \\
\hline & & & & & 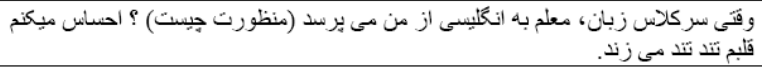 & 9 \\
\hline & & & & & 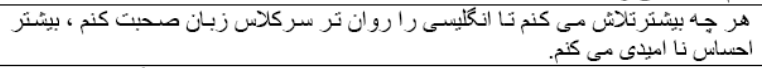 & 10 \\
\hline & & & & & 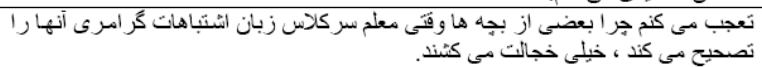 & 11 \\
\hline & & & & & 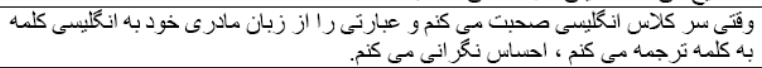 & 12 \\
\hline & & & & & فكر انظليبسى صحبت كردن با لهجه بسيار خوب سر كلاس زبان آز ارم مى دهد. & 13 \\
\hline & & & & & 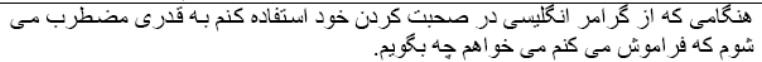 & 14 \\
\hline & & & & & 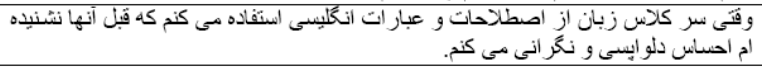 & 15 \\
\hline & & & & & 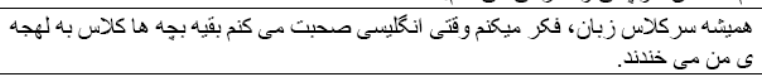 & 16 \\
\hline & & & & & وقتَى سر كلاس زبان، انكليسى را با كُ امز غلط صحبت مى كنم احساس ترس مى كنم. & 17 \\
\hline & & & & & 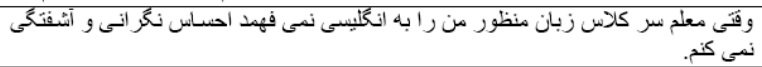 & 18 \\
\hline
\end{tabular}

\section{ACKNOWLEDGMENT}

I would like to thank Mr. Haerizadeh, the head of Zaban Sara Language Institute (Mashhad), for collaborating with the researcher during the process of data collection.

\section{REFERENCES}

[1] Aida, Y. (1994). Examination of Horwitz, Horwitz, and Cope's construct of foreign language anxiety: The case of students of the Japanese. Modern Language Journal, 78(2), 155-168.

[2] Alpert, R., \& Haber, R.N. (1960). Anxiety in academic achievement situation. Journal of Abnormal and Social Psychology, 61, 207-215.

[3] Aydin, B. (1999). A Study of the Two Sources of Foreign Language Classroom Anxiety. Unpublished Doctoral Dissertation. Anadolu University, Eskisehir.

[4] Bacon, S. (1989). Listening for real in the second language classroom. Foreign Language Annals, 22, 543-551.

[5] Bailey, K. M. (1983). Competitiveness and anxiety in adult second language learning: Looking at and through the diary studies. In H. W. Seliger \& M. H. Long (Eds.), Classroom oriented research (pp. 67-103). Rowley, MA: Newbury House.

[6] Brown, H.D. (2000). Principle of Language Learning and Teaching (4 ${ }^{\text {th }}$ Ed.). Pearson Education: Longman.

[7] Casado, M. A. \& Dereshiswsky, M. I. (2004). Effect of Educational Strategies on Anxiety in the Second Language. College Student Journal, 38 (1), 23-35.

[8] Chang, G.B.Y. (1996). A study of anxiety in Chinese EFL learners. Teaching and Research, 18, 68-90.

[9] Chang-Cheng, J. (2005). The relationship of foreign language anxiety of oral performance achievement, teacher characteristics and in-class activities. Unpublished M.A. Thesis, Ming Chun University, Taipei City.

[10] Chastain, K. (1975). Affective and Ability Factors in Second Language Acquisition, Language Learning, 25, 153-161.

[11] Cheng, Y. (2002). Factors associated with foreign language writing anxiety. Foreign Language Annals, 35, $647-656$.

[12] Cheng, Y., Horwitz, E., \& Schallert, D. (1999). Language anxiety: Differentiating writing and speaking components. Language Learning, 49, 417-446.

[13] Cubukcu, F. (2007). Foreign Language Anxiety. Iranian Journal of Language Studies, 1(2), 133-142.

[14] Daly, J., \& Wilson, D. A. (1983). Writing apprehension, self-esteem and personality. Research in the Teaching of English, 17, $327-342$.

[15] Dusek, J. B. (1980). The development of test anxiety in children. In Irwin B. Sarason (Ed.), Test Anxiety: theory, research, and applications (pp. 87-110). Hillsdale, NJ: Lawrance Erlbaum Associates, Inc.

[16] Elkhafaifi, H. (2005). Listening comprehension and anxiety in the Arabic language classroom. Modern Language Journal, 89(9), 206-220.

[17] Ellis, R. (1997). Second Language Acquisition. Oxford: Oxford University Press. 
[18] Ganschow, L., Sparks, R., Anderson, R., Javorshy, J., Skinner, S., \& Patton, J. (1994). Differences in language performance among high-, average-, and low-anxious college foreign language learners. The Modern Language Journal, 78(1), 41-55.

[19] Gardner, R. C., Lalonde, R. N., Moorcroft, R., \& Evers, F. T. (1987). Second language attrition: The role of motivation and use Journal of Language and Social Psychology, 6, 29-47.

[20] George, D., \& Mallery, P. (2003). SPSS For Windows Step By Step: A Simple Guide And Reference (4th ed.). Boston: Allyn \& Bacon.

[21] Goshi, M. (2005). Foreign Language classroom Anxiety: How Should the Classroom Teacher Deal with it? Journal of the School of Marine Science and Technology, 3(2), 61-66.

[22] Gregersen, T. S. (2005).Non verbal cues: Clues to the detection of foreign language anxiety. Foreign Language Annuals, 38, $388-400$.

[23] Horwitz, M. B, Horwitz, E. K., \& Cope, J. A. (1986). Foreign language classroom anxiety. Modern Language Journal, 70(2), $125-132$.

[24] Horwitz, E. K. (2001). Language Anxiety and Achievement. Annual Review of Applied Linguistics, 21,112-126.

[25] Jackson, J. (2001). Reluctance in Second Language: Case Discussions. System, 30, 65-84.

[26] Kleinmann, H. H. (1977). Avoidance behavior in adult second language acquisition. Language Learning, 27, 93-107.

[27] Kota, O. (2005). Language anxiety from the teacher's perspective: Interviews with seven experienced ESL/EFL teachers. Journal of Language Learning, 3(1), 230-249.

[28] Levine, G. S. (2003). Student and instructor beliefs and attitudes about target language use, first language use, and anxiety: Report of a questionnaire survey. Modern Language Journal, 87(3), 343-364.

[29] Lund, R. J. (1991). A comparison of second language reading and listening comprehension. Modern Language Journal, 73, $32-40$.

[30] MacIntyre, P. D., \& Gardner, R. C. (1989). Anxiety and second-language learning: Toward a theoretical clarification. Language learning, 39, 251-275.

[31] MacIntyre, P. D., \& Gardner, R. C. (1994). The subtle effects of language anxiety on cognitive processing in the second language learning. Language learning, 44(2), 283-305.

[32] MacIntyre, P. D., Noels, K. A. \& Clement, R. (1997). Biases in self-ratings of second language proficiency: The role of language anxiety. Language Learning, 47(2), 265-287.

[33] Marwan, A. (2007). Investigating students' foreign language anxiety. Malaysian Journal of ELT Research, 3, 37-55.

[34] Matsuda, S., \& Gobel, P. (2001). Quiet apprehension: Reading and classroom anxieties. JALT Journal, 23, $227-247$.

[35] McCroskey, J. C. (1987). Willingness to communicate. In J. C. McCroskey \& J. A. Daly (Eds.), Personality and interpersonal communication (pp. 129-156). Thousand Oaks, CA: Sage.

[36] McLaughlin, B. (1987). Theories of Second Language Learning. New York: Edward Arnold.

[37] Na, Z. (2007). A Study of High School Students' English Learning Anxiety. Iranian EFL Journal, 9(3), 22-34.

[38] Onwuegbuzie, A. J., Bailey, P., Christine, E., \& Daley C. E. (1999). Factors associated with foreign language anxiety. Applied sociolinguistics, 20(2), 218-239.

[39] Pappamihiel, N. E. (2002). English as a second language students and English language anxiety: Issues in the mainstream classroom. Proquest Education Journal, 36(3), 327-355.

[40] Price, M. L. (1991). The subjective experience of foreign language anxiety: Interviews with anxious students. In E. K. Horwitz \& D. J. Young (Eds.), Language anxiety: From theory and research to classroom implications (pp. 101-108). Englewood Cliffs, NJ: Prentice Hall.

[41] Sadighi, F., Sahragard, R., \& Jafari, S.M. (2009). Listening Comprehension and Foreign Language Classroom Anxiety among Iranian EFL learners. Iranian EFL Journal, 3(7), 137-152.

[42] Saito, Y., \& Samimy, K. K. (1996). Foreign language anxiety and language performance: A study of learner anxiety in beginning, intermediate, and advanced-level college students of Japanese. Foreign Language Annals, 29(2), $239-251$.

[43] Scovel, T. (1978). The effect of affect on foreign language learning: A review of the anxiety research. Language Learning, $28,129-142$

[44] Selinker, L. (1972). Interlanguage. International Review of Applied Linguistics, 10, 209-231.

[45] Sellers, V. D. (2000). Anxiety and reading comprehension in Spanish as a foreign language. Foreign Language Annals, 33, 512-520.

[46] Spielberger, C. D. (1983). Manual for the State Trait Anxiety Inventory. California: Consulting Psychologists Press.

[47] Spielmann, G., \& Radnofsky, M. L. (2001). Learning language under tension: New directions from a qualitative study. The Modern Language Journal, 85(2), 259-278.

[48] Tarone, E. (1983). On the variability of interlangugae systems. Applied Linguistics, 4, 142-163.

[49] Worde, R.V. (1998). An investigation of students' foreign language anxiety. Retrieved March 7, 2011, from http://www. Eric. ed. gov/ERIC web portal

[50] Young, D. J. (1990). An investigation of students' perspectives on anxiety and speaking. Foreign Language Annals, 23(6), 539-553.

[51] Young, D. J. (1991). Creating a low-anxiety classroom environment: What does the language anxiety research suggest? Modern Language Journal, 75, 425-439.

[52] Young, D. J. (1992). Language anxiety from the foreign language specialist's perspective: Interviews with Krashen, Omaggio Hadley, Terrell, and Rardin. Foreign Language Annals, 25(2), 157-172. 


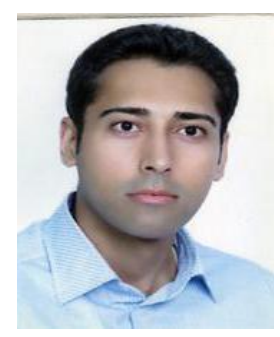

Masoud Mahmoodzadeh received his B.A. degree in English Language Translation from Imam Reza University (pbuh), Mashhad, Iran. He then got his M.A. degree in TEFL at Sheikhbahaee University, Isfahan. He has been teaching English to Iranian EFL learners at several language institutes for more than seven years. He has also taught General English courses at Sheikhbahaee University, Isfahan. As a researcher, his research studies have contributed to some local and international journals including Iranian EFL Journal, Theory and Practice in Language Studies, and Journal of Language Teaching and Research. His main areas of interest include second language acquisition, language teaching methodology, curriculum planning/evaluation, and the role of affective variables in language teaching, especially foreign language anxiety. 